\title{
Post Blood Transfusion Reversible Cerebral Vasoconstriction with Posterior Leukoencephalopathy Syndrome
}

\author{
Kan Transfüzyonu Sonrası Reversibl Serebral Vazokonstriksiyon ile Birlikte Posterior \\ Lökoensefalopati Sendromu
}

\author{
(1) Kiran Kumar Ramineni1, (1) Ravi Kanth Jakkani2 \\ ${ }^{1}$ Yashoda Super Speciality Hospital, Clinic of Neurology, Hyderabad, Telangana, India \\ ${ }^{2}$ Yashoda Super Speciality Hospital, Clinic of Radiology, Hyderabad, Telangana, India
}

\begin{abstract}
Reversible Cerebral Vasoconstriction syndrome is an uncommon and often under-diagnosed neurologic disorder. It is characterized by thunderclap headache with or without focal neurologic deficits and seizures. Common provoking factors include postpartum status and vasoactive drugs. We report a case of reversible Cerebral Vasoconstriction syndrome with posterior leukoencephalopathy following packed red blood cell transfusion, which is a rare complication of this commonly used modality of treatment for severe anaemia.
\end{abstract}

Keywords: Reversible, cerebral vasoconstriction, leukoencephalopathy, blood transfusion, anaemia

$\ddot{O} \mathbf{z}$

Reversibl Serebral Vazokonstrüksiyon sendromu, nadir görülen ve sıklıkla teşhis edilemeyen nörolojik bir bozukluktur. Fokal nörolojik defisitler ve nöbetlerin eşlik edebildiği "gök gürültüsü” baş ağrısı ile karakterizedir. Sık görülen provoke edici faktörler arasında doğum sonrası dönem ve vazoaktif ilaçlar bulunur. Bu olgu bildiriminde, şiddetli anemi için yaygın olarak kullanılan bir tedavi yöntemi olan eritrosit süspansiyonu transfüzyonunun nadir bir komplikasyonu olarak, transfüzyonu takiben reversibl serebral vazokonstrüksiyon ile birlikte Posterior Lökoensefalopati sendromu gelişen bir hasta sunulmaktadır.

Anahtar Kelimeler: Reversibl, serebral vazokonstrüksiyon, lökoensefalopati, kan transfüzyonu, anemi

\section{Introduction}

Reversible Cerebral Vasoconstriction syndrome (RCVS) typically presents with acute-onset thunderclap headache. Additional manifestations include seizures and focal neurologic deficits. Female preponderance is common. It can occur spontaneously or be provoked by postpartum status, vasoactive substances including illicit drugs, selective serotonin reuptake inhibitors, and triptans $(1,2)$.

Blood transfusion is commonly used for correction of severe anaemia. RCVS with posterior leukoencephalopathy is a very rare complication following blood transfusion. So far, only limited data are available on this entity (3). In this report, we describe the clinical and imaging features of a middle-aged female who developed RCVS with Posterior Leukoencephalopathy syndrome following packed red blood cell (RBC) transfusion for correction of severe anaemia.

\section{Case Report}

A 46-year-old woman presented with a history of acute onset of recurrent thunderclap headaches for three days. She developed two episodes of generalized tonic-clonic seizures and lapsed into altered sensorium, following which she was brought to the emergency department. There was no history of fever, vomiting or weakness of limbs, and no history of head trauma. She received paracetamol tablet $650 \mathrm{mg}$ twice a day during the first two days of headache. There was no history of vasoactive drug use including illicit drugs. There was no past history of migraine or thunderclap headaches. No history of prior stroke or coronary artery disease. She was not a known hypertensive or diabetic. She had two living children with the last childbirth 18 years ago, following which she had undergone family planning surgery and both peripartum periods were uneventful.

One week prior to the onset of headache she received four units of packed RBC transfusion for the correction of anaemia by

Address for Correspondence/Yazışma Adresi: Ravi Kanth Jakkani MD, Yashoda Super Speciality Hospital, Clinic of Radiology, Hyderabad, Telangana, India Phone: +919177534069 E-mail: ravikanthjakkani@gmail.com ORCID: orcid.org/0000-0002-7371-9273

Received/Geliş Tarihi: 11.08.2019 Accepted/Kabul Tarihi: 30.01 .2020

${ }^{\circ}$ Copyright 2020 by Turkish Neurological Society

Turkish Journal of Neurology published by Galenos Publishing House. 
her primary care physician with baseline haemoglobin of $4 \mathrm{~g} / \mathrm{dl}$, which improved to $9 \mathrm{~g} / \mathrm{dl}$ post-transfusion. The immediate posttransfusion period was uneventful. She had a history of menorrhagia for the past three years with multiple uterine fibroids and was advised to undergo a hysterectomy, which she had deferred.

On examination, she was drowsy and arousable. Her vitals were as follows: temperature $37.2^{\circ} \mathrm{C}$, pulse rate $110 / \mathrm{min}$ regular, blood pressure $110 / 80 \mathrm{~mm} \mathrm{Hg}$, and respiratory rate $22 / \mathrm{min}$. The fundus examination was normal, pupils $3 \mathrm{~mm}$ bilaterally equal and reacting to light. No asymmetry of limb movements was noted, and deep tendon reflexes were brisk with withdrawal plantars. No signs of meningeal irritation. In the emergency department, she received $4 \mathrm{mg}$ intravenous lorazepam, $1000 \mathrm{mg}$ of intravenous levetiracetam, and was sent to the neuro intensive care unit.

Laboratory investigations revealed haemoglobin of $9 \mathrm{~g} / \mathrm{dl}$, total white blood cell count 10,000/cubic mm, platelets 2 lakh/ cubic $\mathrm{mm}$, and erythrocyte sedimentation rate $20 \mathrm{~mm} / \mathrm{hr}$. Random blood sugar was $80 \mathrm{mg} / \mathrm{dl}$, glycosylated haemoglobin $5.4 \%$, and serum creatinine $0.8 \mathrm{mg} / \mathrm{dl}$. Serum electrolytes, liver function tests, serum calcium, and magnesium were within normal limits. Serum ferritin was low with normal vitamin B12, folate, and homocysteine levels. HIV $1 \& 2$, venereal disease research laboratory were non-reactive. Chest X-ray, electrocardiography, and 2D echo were normal. Abdomen and pelvis ultrasound revealed multiple uterine fibroids. Rheumatoid factor, ANA profile, and C\&P ANCA were negative. Illicit drug screening of urine for vasoactive substances such as marijuana and cocaine was negative.

Plain magnetic resonance imaging (MRI) of the brain and contrast with MR angiography revealed T2 and fluid attenuation inversion recovery hyperintensities in bilateral cerebral and cerebellar hemispheres with multifocal cerebral vasoconstrictions with beading (Figure 1). Cerebrospinal fluid analysis was normal.

Based on the clinical and imaging findings, the possibility of RCV with Posterior Leukoencephalopathy syndrome was considered.

Intravenous levetiracetam $500 \mathrm{mg}$ twice a day, and paracetamol tablet $650 \mathrm{mg}$ thrice a day were continued. Nimodipine tablet $60 \mathrm{mg}$ four times a day was added with close monitoring of blood pressure. By $24 \mathrm{hrs}$ post admission she regained normal sensorium with transient blurring of vision. No other focal neurologic deficits were noted. She maintained improvement and had no further seizures. Her headache subsided by one week and she was discharged in a stable condition on oral levetiracetam $500 \mathrm{mg}$ twice a day and nimodipine $60 \mathrm{mg}$ three times a day tapered over the next four weeks, therapeutic doses of oral iron continued. She was counselled regarding beneficial lifestyle measures and avoidance of potential triggers and the possibility of recurrence of symptoms. Follow-up MRI brain with an angiogram after 10 weeks revealed near-total resolution of the white matter changes, edema, and vasoconstriction (Figure 2). A final diagnosis of RCV with posterior leukoencephalopathy syndrome as a complication of RBC transfusion for the correction of severe anaemia was made. Six months later she had undergone laparoscopic hysterectomy and the postoperative period was uneventful. Over the next year, she had no manifestations of relapse.

\section{Discussion}

Blood transfusion-related complications can be immunologic or infectious (4). Neurologic complications following blood transfusion are rarely reported. The diagnostic criteria used for post-transfusion RCVS includes acute severe often thunderclap headache with or without focal neurologic deficits and seizures, segmental vasoconstriction of cerebral arteries confirmed using computed tomography/MRI angiography or catheter angiography, and complete or substantial normalization within 12 weeks after onset. A history of receiving RBC cell transfusion because of severe anaemia in the preceding three months helps to rule out other mimickers such as central nervous system angitis or subarachnoid haemorrhage related vasospasm (3). Typical clinical features of RCVS after blood transfusion include thunderclap headaches, seizures, and focal neurological deficits such as vision impairment, hemiparesis, and dysarthria. Previous reports on RCVS after blood transfusion described middle-aged women with chronic severe anaemia with average baseline haemoglobin of less than $3 \mathrm{~g} / \mathrm{dl}$. Blood transfusion increased the haemoglobin by at least $4.5 \mathrm{~g} / \mathrm{dl}$ from baseline over a period of less than one week and neurologic symptoms developed around one week after the last transfusion with a range of 2 to 13 days $(3,5)$. Our patient received four units of packed RBCs over three days with a haemoglobin improvement to $9 \mathrm{~g} / \mathrm{dl}$ from a baseline value of $4 \mathrm{~g} / \mathrm{dl}$ and neurologic manifestations started 7 days after the last transfusion. The development of classical thunderclap headache with seizures followed by altered sensorium warranted further evaluation for the possibility of RCVS. Brain MRI with angiogram confirmed the same. Another important observation was the extensive involvement of anterior and posterior cerebral circulations, which was an infrequent finding

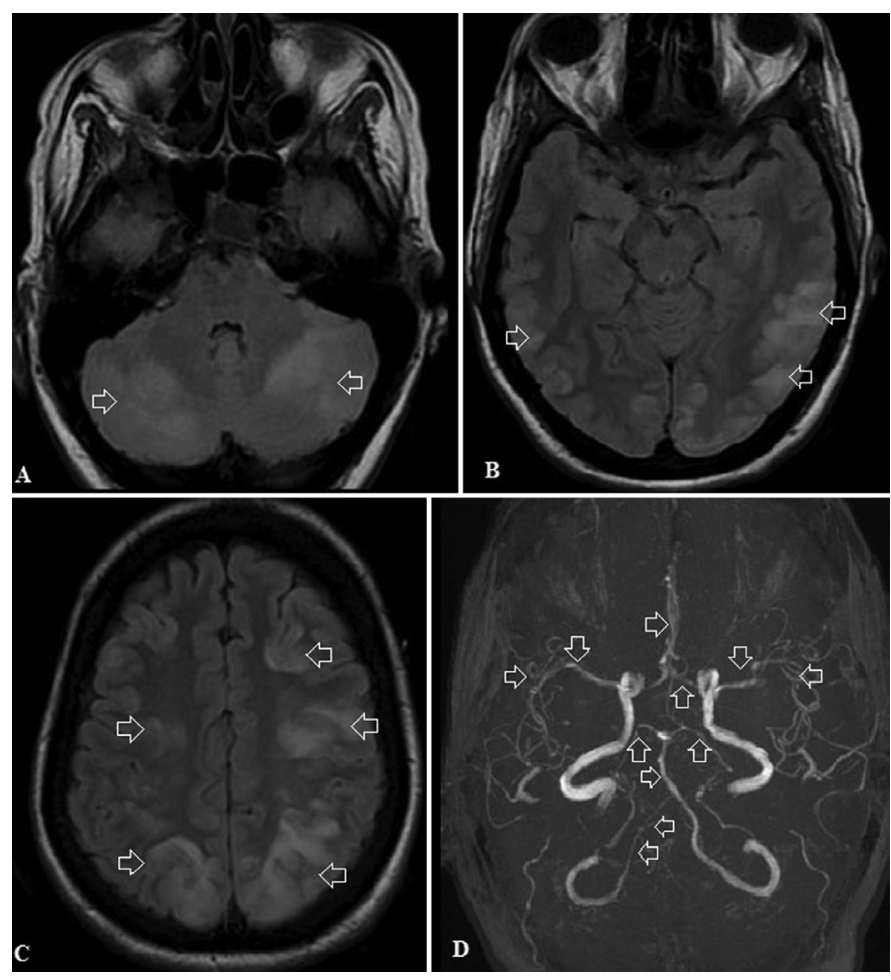

Figure 1. Axial FLAIR (A, B and C) and D MIP MRA (images of the brain show multifocal FLAIR hyperintensities in bilateral cerebellar hemispheres and cerebral hemispheres with multifocal areas of intracranial arterial stenosis with irregular beaded appearance (white arrows)

FLAIR: Fluid attenuation inversion recovery, MIP: Maximum intensity projection, MRA: Magnetic resonance angiogram 

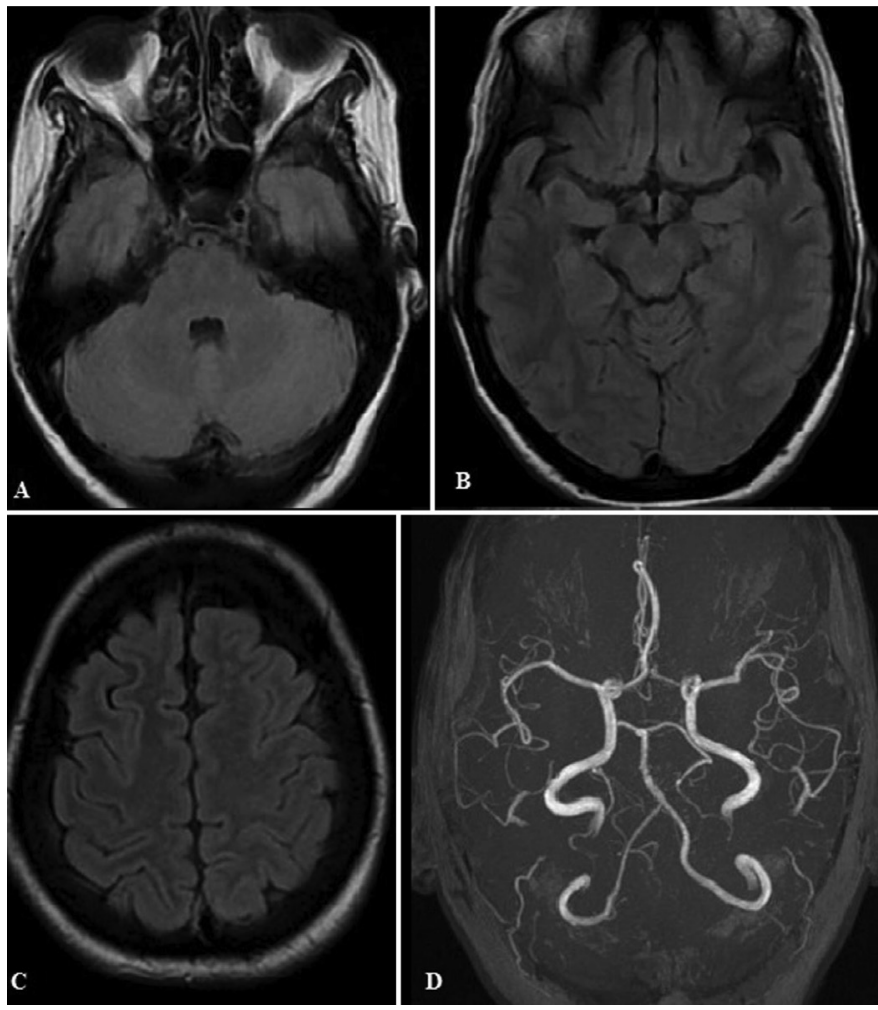

Figure 2. Follow up MRI, Axial FLAIR (A, B and C) and D MIP MRA images of the brain show complete resolution of signal changes in the brain parenchyma with near-complete reversal of arterial narrowing FLAIR: Fluid attenuation inversion recovery, MIP: Maximum intensity projection, MRA: Magnetic resonance angiogram

in the previous series (3). In addition, brain parenchymal changes were consistent with posterior reversible leukoencephalopathy. The co-occurrence of PRES in RCVS has been described previously (5). Both these conditions share common predisposing factors, clinical, radiologic features, and pathophysiologic mechanisms.

Almost all case reports on RCVS after blood transfusion included patients with chronic severe anaemia and were not due to acute blood loss. Chronic anaemia may be accompanied by cerebral vasodilatation to compensate for ischemic hypoxia. A rapid rise in haemoglobin and viscosity during blood transfusion may result in a loss of vasodilatation and increase vascular resistance causing cerebral vasoconstriction. Biochemical and immunologic factors including catecholamines, endothelin, and nitric oxide may play a role in the pathophysiology of vasoconstriction (6). The latency of neurologic symptom onset depends on multiple factors such as the amount, duration of blood transfusion, patient comorbidities, and the rate of centripetal progression of vasoconstriction. Endothelial dysfunction after blood transfusion may affect the regulation of cerebral arterial tone and trigger vasoconstriction. Subsequent hypoperfusion, breakdown of the blood brain barrier, and vasogenic edema results in reversible posterior leukoencephalopathy. Our patient received no vasoactive drugs hence drug-induced RCVS was unlikely. Concurring with the existing literature (7), we consciously avoided steroids and administered oral nimodipine, which was tapered over the next four weeks. There was no recurrence of thunderclap headache and seizure throughout the follow-up period. Significant resolution of MRI brain imaging and angiographic abnormalities was documented, confirming the diagnosis of RCV with posterior leukoencephalopathy syndrome. Together with this report, the majority of previous reports on RCVS following blood transfusion described middle-aged women from Asian countries with severe chronic anaemia, which raises the possibility of genetic and ethnic factors playing a role in the predisposition for this rare complication $(3,5)$. This case highlights the importance of timely diagnosis and appropriate management of a neurologic emergency following the correction of severe anaemia. Patients and the primary care medical fraternity should be counselled regarding this uncommon neurologic syndrome following blood transfusion, the avoidance of potential triggers, and the possibility of recurrence (8). Larger prospective studies on this topic can better address issues such as the correlation between the severity of anaemia, the pattern of involvement of cerebral vascular territories in RCVS, and long-term outcomes.

Although rare, RCV with Posterior Leukoencephalopathy syndrome can occur as a complication of blood transfusion, especially in patients with chronic severe anaemia. Following packed RBC transfusion, development of thunderclap headache, seizures or focal neurologic deficits should alert the physician to thoroughly evaluate for the possibility of this potentially treatable neurologic emergency.

\section{Ethics}

Informed Consent: Obtained from patient before submission. Peer-review: Externally peer-reviewed.

\section{Authorship Contributions}

Surgical and Medical Practices: K.K.R., R.K.J., Concept: K.K.R., R.K.J., Design: K.K.R., R.K.J., Data Collection or Processing: K.K.R., R.K.J., Analysis or Interpretation: K.K.R., R.K.J., Literature Search: K.K.R., R.K.J., Writing: K.K.R.

Conflict of Interest: No conflict of interest was declared by the authors.

Financial Disclosure: The authors declared that this study received no financial support.

\section{References}

1. Ducros A, Boukobza M, Porcher R, et al. The clinical and radiological spectrum of reversible cerebral vasoconstriction syndrome. A prospective series of 67 patients. Brain 2007;130:3091-3101

2. Ramineni KK, Jakkani RK, Girgani S, Balani A, Satyanarayan S. Triptaninduced reversible cerebral vasoconstriction syndrome presenting with thunderclap headache and paraparesis. Neurologist 2018;23:160-162.

3. Liang H, Xu Z, Zheng Z, Lou H, Yue W. Reversible cerebral vasoconstriction syndrome following red blood cells transfusion: a case series of 7 patients. Orphanet J Rare Dis 2015;10:47.

4. Sahu S, Hemlata, Verma A. Adverse events related to blood transfusion. Indian J Anaesth 2014;58:543-551.

5. Dou YH, Fuh JL, Chen SP, Wang SJ. Reversible cerebral vasoconstriction syndrome after blood transfusion. Headache 2014;54:736-744.

6. Calic Z, Cappelen-Smith C, Zagami AS. The reversible cerebral vasoconstriction syndrome. Intern Med J 2015;45:599-608.

7. Singhal AB, Topcuoglu MA. Glucocorticoid-associated worsening in reversible cerebral vasoconstriction syndrome. Neurology 2017;88:228236.

8. Chen SP, Fuh JL, Lirng JF, Wang YF, Wang SJ. Recurrence of reversible cerebral vasoconstriction syndrome: a long-term follow-up study. Neurology 2015;84:1552-1558. 